\title{
Using Componential Analysis to Evaluate Translation Results
}

\author{
Sri Dewiyanti and Hani Suryani \\ Department of English Language, Politeknik Negeri Bandung, Indonesia \\ Email: sdewiyanti@polban.ac.id \\ hanisurya140711@gmail.com
}

\begin{abstract}
Componential analysis is an analysis of the meaning of a word by breaking down the word into different pieces called 'component parts'. This kind of analysis could be helpful in the process of translation to choose the most accurate and closest lexical equivalents. This study aims to weigh the use of componential analysis for evaluating the accuracy of the translated words. The data are five Indonesian dish names and their English translation printed on the packaging of instant spices. The study proves that by using componential analysis inappropriate translation techniques can be identified and better techniques can be decided to produce more accurate translated words, and some possible translation for each cultural word can be produced.
\end{abstract}

Key Words: cultural words, translation techniques, component analysis, Indonesian dish names

\section{Introduction}

Translation is not solely changing a text from one language into another but also transferring its meaning. Nida and Taber (1982) and Newmark (1988) define translation by focusing on the importance of meaning. However, the process of transferring meaning by using other language is often problematic, especially when the text consists of cultural terms.

For example, food products such as instant cooking spices produced by Indonesian companies and are exported to other countries are labeled used bilingual language (i.e Indonesian and English). The names of the dishes and the ingredients are translated into English. They may consist of cultural terms, and lots of Indonesian words related to food do not have their equivalents in English. This may result in loss of key information and might not convey how the food to be.

This study used componential analysis (CA) to assess whether the dish names printed on the food label have been translated into English accurately and could achieve maximal equivalence. According to Newmark (1988) the main process of CA in translation is comparing a source language (SL) word and a target language (TL) word which has a similar meaning although it is not one-to-one equivalent. Therefore, the characteristics of CA make it possible to assess the translation results of those cultural terms because this technique can anatomise a word and infer its meaning. As stated by Carter (1987), CA is a technique of finding the connection of meaning by breaking down each word into complicated items.

The formulated question of this study is to what extent componential analysis can evaluate the translation results.

\section{Literature Review}

CA was invented to identify semantic relationships between words which had no phonological similarities and to create a meta language that would enable people to translate lexical units, which had no equivalents in particular foreign languages, or their nearest equivalents were inexact (Bright, 1992 in International Encyclopedia of Linguistics). 
Although translating cultural words into another language may be problematic, the closest equivalence of the translated words must be employed (Nida, 1975). Newmark (1988) includes CA as one of strategies in translating cultural words. The use of CA in translating cultural words is to provide an accepted translation. CA is more precise and limiting than paraphrase or definition, since this procedure are picking out characteristics in their order of importance. Moreover, Newmark (1998) states that "The only purpose of CA in translation is to achieve the greatest possible accuracy, inevitably at the expense of economy" (p.117). Moreover, CA could be used for analysing the structure of words meaning. Therefore, the essential features related to culture could be revealed (Ottenheimer, 2006: 20).

Leech (1981) affirms that CA breaks down the meaning of words into its semantic features. Nida (1975) identifies three fundamental classes of semantic features. They are common features, diagnostic features and supplementary features. Common features are features that are shared by all the meaning being compared. Diagnostic features are features that differentiate the meaning of any set, and (3) supplementary features are features which are not important to describe the aspect of meaning but which may add additional information in contrasting the meaning. Nida (1975) also identifies four basic types of semantic features which are shared by the language being compared. They are object elements, events elements, relational elements and quality elements.

When making comparison, symbols of + and - are used to show the presence and absence of a feature. The + symbol is used to show the presence of a feature and the - symbol is used to show the absence of a feature (Saeed, 2009).

\section{Methods}

The data were collected from the packaging of Indonesian instant spices which present the texts bilingually. Five packaging were selected randomly from various brands.

The analysis was presented in description and table. The description was used to explain the analysis. The componential analysis was presented in the form of table listing the features to be compared and using + and - symbols. Symbol of + shows the presence of a feature, and symbol of - shows the absence of a feature.

The diagnostic features for the dishes are taken from the description and main characteristic of each dish. From the table of diagnostic features, the accuracy of the translated word can be marked by calculating the total number of + and - symbols and showing percentage of the ratio of the presence features from SL and TL. This will show whether the translation results are accurate or not.

Translated word which is labelled 'accurate' means that the target language (TL) has similar feature as source language (SL). It can be seen from the percentage of the total number of the similar features marked by + symbol in the table of componential analysis. The higher the score the more accurate is the translated words.

\section{Discussion}

This study focused on the Indonesian dish names and their English versions printed on the packaging. The dish names to be analysed are Nasi Kuning, Rawon, Sayur Asem, Opor, and Lodeh. These dishes are very popular in Indonesia.

The component analysis was used to assess the accuracy of the translated results. Table 1 shows the componential analysis score of each dish name. The score range is from 20 to 100 . It means producing qualified translation results of the dish names printed on the packaging is challenging. 
Table 1 The Score of Componential Analysis for Each Dish Name

\begin{tabular}{|l|l|l|c|l|}
\hline No & Indonesian & \multicolumn{1}{|c|}{ English } & $\begin{array}{l}\text { Score } \\
\text { of CA }\end{array}$ & \multicolumn{2}{|c|}{ Possible Translation } \\
\hline 1 & $\begin{array}{l}\text { Nasi } \\
\text { Kuning }\end{array}$ & Yellow Rice & 60 & Indonesian Yellow Rice \\
\hline 2 & Rawon & East Java Meat Soup & 20 & $\begin{array}{l}\text { Indonesian Diced Beef in } \\
\text { Black Soup }\end{array}$ \\
\hline 3 & Sayur Asem & $\begin{array}{l}\text { Sweet \& Sour } \\
\text { Vegetable Soup with } \\
\text { Tamarind }\end{array}$ & 100 & $\begin{array}{l}\text { Indonesian Sweet \& Sour } \\
\text { Vegetable Soup with } \\
\text { Tamarind Chicken }\end{array}$ \\
\hline 4 & Opor & White Curry & 75 & $\begin{array}{l}\text { Indonesian Braised Chi } \\
\text { in Coconut Milk }\end{array}$ \\
\hline 5 & Lodeh & Vegetable Stew & 75 & $\begin{array}{l}\text { Indonesian Mix Vegetables } \\
\text { with Coconut Milk Soup }\end{array}$ \\
\hline
\end{tabular}

The results of the componential analysis is explained in the following sections.

\section{a. Nasi Kuning $\rightarrow$ Yellow Rice}

Nasi kuning seasoning product was translated into Yellow Rice. Based on the cultural word categories proposed by Newmark (1988), the phrase Nasi kuning can be categorized into material cultural word because this phrase refers to food. In this case, nasi is translated into rice and kuning is translated into yellow. It is obviously seen that literal translation is used in translating Nasi Kuning into Yellow Rice.

In Indonesia, Nasi Kuning is a rice dish cooked with coconut milk and turmeric as main ingredients. The turmeric gives the rice a yellow colour. It is usually served on a special event in the form of a cone called tumpeng, which is symbolised good fortune, wealth and dignity. A variety of side dishes are served together with this rice.

However, the term yellow rice is also common as a traditional yellowcolored rice dish in Spanish, Cuban, Caribbean, Afghan, South Africa. Achiote (annatto seeds) can be used to give the rice its color. It is usually served with Bobotie. The main ingredients are rice, turmeric and butter.

From the description about nasi kuning and yellow rice, the main features that are the dominant ingredient can be broken down into the following diagnostic features as seen in Table 2.

Table 2 Diagnostic Features between "Nasi Kuning" and "Yellow Rice"

\begin{tabular}{|l|c|c|}
\hline \multirow{2}{*}{ Diagnostic Features } & SL & TL \\
\cline { 2 - 3 } & Nasi Kuning & Yellow Rice \\
\hline Food & + & + \\
\hline Main ingredients: & + & + \\
rice & + & + \\
turmeric & + & - \\
coconut milk & + & - \\
\hline Often served at parties and & & \\
opening ceremonies & & \\
\hline
\end{tabular}

It can be seen that the diagnostic features compare the words nasi kuning and yellow rice. Both of the terms, nasi kuning and yellow rice have 'food' features (marked by the + 
symbol). From the composition of the main ingredients, both nasi kuning and yellow rice have the same features that is rice and turmeric. Therefore, it is marked by + symbol. However, another main ingredient in nasi kuning, which is coconut milk (marked by +), is not present in the ingredient of Yellow Rice (marked by symbol -).

Another feature is concerning with how the dish is served. Nasi kuning is often served on special occasions (marked by + ), but Yellow Rice is not served in such occasion (marked by - )

In conclusion, both nasi kuning and yellow rice are food made of rice and turmeric. Nasi kuning has coconut milk for the ingredient and is often served at special occasions, but yellow rice does not have these features.

There are five specific features for nasi kuning, whereas yellow rice has only three features which are similar (marked by + ) to nasi kuning. The CA score is calculated as follows: The number of similar features in yellow rice, that is 3 is divided by the number of specific features of nasi kuning multiplied by 100. It become 60. Therefore, the use of Literal Translation technique in translating nasi kuning into yellow rice has a score of 60 .

This score shows that, in this case, literal translation is not suitable for translating nasi kuning. Adding more information to the translated words would convey how the food to be. The possible translation for the phrase nasi kuning is Indonesian Yellow Rice. The word Indonesian should be added to the translated words to give more accurate meaning to the phrase yellow rice, that is Indonesian style for yellow rice.

\section{b. Rawon $\rightarrow$ East Java Meat Soup}

Rawon is traditional food from East Java Province of Indonesia. It is a kind of food made of beef with black soup from keluak as main spice. Keluak or Kluwek is a black nut with hard-shelled and grows in the mangrove swamps of Indonesia and Malaysia.

Table 3 Diagnostic Features between "Rawon" and "East Java Meat Soup"

\begin{tabular}{|l|c|c|}
\hline \multirow{2}{*}{ Diagnostic Features } & SL & TL \\
\cline { 2 - 3 } & Rawon & East Java Meat Soup \\
\hline Food & + & + \\
\hline $\begin{array}{l}\text { Main ingredients: } \\
\quad \begin{array}{l}\text { Diced beef } \\
\text { keluak }\end{array}\end{array}$ & + & - \\
\hline $\begin{array}{l}\text { The color of soup is } \\
\text { black }\end{array}$ & + & - \\
\hline $\begin{array}{l}\text { Served with rice and } \\
\text { bean sprouts }\end{array}$ & + & - \\
\hline
\end{tabular}

From Table 3, it can be seen that the diagnostic features shows that as food, the terms rawon and East Java meat soup are marked by + . The composition of the main ingredients of Rawon are diced beef and keluak (a spice which gives black colour of the soup), but the term East Java meat soup does not have it (marked by -). The others diagnostic feature for Rawon, which are the color of soup is black and served with rice and bean sprouts, do not appear in the term East Java meat soup and it was marked by - .

It can be concluded that the words Rawon and East Java meat soup are kinds of food. Rawon is made of beef, but East Java meat soup can be made of any kind of meat. Moreover, rawon soup has black colour from kluwek but East Java meat soup do not show kluwek element in it. 
From the total number of diagnostic feature, translating rawon into East Java Meat Soup has score of 20. Adding more detail information in translating the word Rawon would be more meaningful and convey how the dish looks like. Therefore, possible translation of Rawon is Indonesian diced beef in black soup.

c. Sayur Asem $\rightarrow$ Sweet and Sour Vegetable Soup with Tamarind

Sayur asem is an Indonesian tamarind dish. The vegetables may consist of peanuts, young jackfruit, long beans, melinjo, bilimbing, corn, which are cooked in tamarind-based soups. Beef stock could be added to enrich the flavour.

The word sayur asem was translated into sweet \& sour vegetable soup with tamarind. It is described the word sayur asem by its form and its main ingredient that is tamarind.

\section{Table 4 Diagnostic Features between Sayur Asem and Sweet \& Sour Vegetable Soup with Tamarind}

\begin{tabular}{|l|c|c|}
\hline \multirow{2}{*}{ Diagnostic Features } & SL & TL \\
\cline { 2 - 3 } & Sayur Asem & $\begin{array}{c}\text { Sweet \& Sour Vegetable } \\
\text { Soup with Tamarind }\end{array}$ \\
\hline Food & + & + \\
\hline Main ingredients: & + & + \\
Vegetable & + & + \\
Tamarind & & + \\
\hline
\end{tabular}

The diagnostic features in Table 4 identify both dish names as 'food' as. Both words show the same element, which vegetable and tamarind as the main ingredients. Therefore, both sayur asem and sweet \& sour vegetable soup with tamarind have the same features (marked by the '+'symbol). In brief, the words sayur asem and sweet \& sour vegetable soup with tamarind are kind of food. Both sayur asem and sweet \& sour vegetable soup with tamarind convey the meaning that both of them are made of vegetable and tamarind as the main ingredients.

From the total number of diagnostic feature, translating sayur asem into Sweet \& sour vegetable soup with tamarind has the score of 100 . It means that the translated results are accurate. However, there is still possible translation for translating the word sayur asem. The Sayur asem can be translated into Indonesian Sweet \& Sour Vegetable Soup with Tamarind. Even though the sweet \& sour vegetable soup with tamarind' has the similar features and represent the meaning of sayur asem, it could be more informative to put the word Indonesian in order to show the original vegetables of sayur asem.

\section{d. $O p o r \rightarrow$ White Curry}

Opor is a popular dish in Indonesia especially when celebrating Eidul-Fitr mubarok. The main ingredient of Opor is chicken which is cooked and braised in coconut milk. The word opor was translated into white curry, which is adapted from Indian dish. 
Table 5 Diagnostic Features between "Opor" and "White Curry"

\begin{tabular}{|l|c|c|}
\hline \multirow{2}{*}{ Diagnostic Features } & SL & TL \\
\cline { 2 - 3 } & Opor & White Curry \\
\hline Food & + & + \\
\hline Main ingredients: & + & - \\
Chicken & + & + \\
Coconut milk & + & + \\
\hline The color of dish is white & & \\
\hline
\end{tabular}

The diagnostic features in Table 5 identify both dish names as 'food', which the words opor and white curry are marked by the + symbol. Chicken as the main ingredient of opor is marked by the + symbol, but it is marked by - symbol for the words white curry. The features of coconut milk and white colour appear in both dish names, opor and white curry. They are marked by the + symbol. In brief, both words, opor and white curry, convey a similar meaning that is kind of food made of coconut milk which is the color of the dish is white. Another main ingredient of opor is chicken. However, this element does not appear in the words white curry.

From the total number of diagnostic feature, translating opor into white curry has score 75 since the meaning of white curry that adapted from other country is quite different with the word opor. The possible translation for the word opor is Indonesian braised chicken in coconut milk. This term seems to be more accurate to translate the word opor.

e. Lodeh $\rightarrow$ Vegetable Stew

Lodeh is Javanese cuisine. It consists of vegetables in coconut milk soup. The common ingredients for lodeh are young unripe jackfruit, eggplant, chayote, melinjo beans and leafs, long beans, green chili pepper, tofu and tempeh. All ingredients are cooked in coconut milk soups and sometimes enriched with chicken or beef stock.

The word lodeh in the packaging was translated into vegetable stew. It seems that generalization techniques was used in translating the word lodeh. Stew is a type of western food cooked slowly in a small amount of liquid (Cambridge Advanced Learner's Dictionary, 2013)

Table 6 Componential Features between "Lodeh" and "Vegetable Stew"

\begin{tabular}{|c|c|c|}
\hline \multirow{2}{*}{ Diagnostic features } & SL & TL \\
\cline { 2 - 3 } & Lodeh & Vegetable Stew \\
\hline Food & + & + \\
\hline Main ingredients: & + & + \\
vegetables & + & + \\
coconut milk & + & - \\
tempeh/tofu & & \\
\hline
\end{tabular}

The diagnostic features in Table 6 compare the words lodeh and vegetable stew. They identify 'food' as the object, 'vegetables' and 'coconut milk' as the ingredient. At this point, both words, lodeh and vegetable stew, have the same features (marked by the + symbol). On the other hand, the other feature, tempeh/tofu, is the feature of the word lodeh (marked by the 
+ symbol), but it is not informed in the the word vegetable stew (marked by the - symbol). In brief, the words lodeh and vegetable stew convey the meaning of food made of vegetables and coconut milk. However, lodeh put tempeh/tofu as the other ingredients, but vegetable stew does not.

From the total number of diagnostic feature, the use of generalization technique in translating lodeh into vegetable stew has a score of 75 since both of the words have several similar elements. It means that the translated word is quite appropriate. However, they also still have some differences. It will be better to add more detail information in the target language. It can be translated into Indonesian mix vegetables with coconut milk soup.

\section{Conclusions}

Translating cultural words printed on the packaging of Indonesian food products should be conducted carefully. Appropriate translation techniques should be applied for each cultural word. Componential analysis will help to decide the techniques that will be used in translating the cultural words appropriately. Therefore, the equivalence for each cultural word should be considered thoroughly so that the readers could understand easily the words.

Based on the results of componential analysis, the use of literal technique may reduce the element of meaning of the dish names. Furthermore, by using componential analysis some possible translation for each cultural word can be produced. Adding words to the target text could produce better translation, especially in translating cultural words printed on Indonesian food products packaging.

Readibility of the possible translation need to be checked, especially when evaluating the appropriateness of translated words. Further research can evaluate the possible translation by asking the target readers to check the readibility and conduct an analysis about translation techniques of cultural words in other Indonesian products.

To sum up, translating words printed on commercial products needs careful decision to choose appropriate words in order to convey the message. This will help the consumers who buy the product understand the features of the product and how the product used. Moreover, knowledge of translation technique and componential analysis procedure is useful for the proses of translation.

\section{References}

Bright, W. (1992). International Encyclopedia of Linguistics, Vol. 1. Oxford: Oxford University Press.

Cambridge Advanced Learner's Dictionary (4th ed). (2013). Cambridge University Press.

Carter, R. (1987). Vocabulary: Applied linguistic perspectives. London: Allen \& Unwin.

Leech, Geoffrey. (1981). Semantics: The study of meaning. Harmondsworth: Penguin Ltd.

Newmark, P. (1988). A textbook of translation, London: Prentice Hall International.

Nida, E. \& Taber, C. (1969). Theory and practice of translation. London: United Bible Societies.

Ottenheimer, Harriete. 2006. The Anthropology of language: An introduction to linguistic anthropology. Virginia: Thomson, Wadsworth.

Saeed, John I. (2009). Semantics (3rd ed). United Kingdom: Wiley Blackwell. 